\title{
АРХЕТИПНЕ ПІДГРУНТЯ І ПОЕТИКА ПОВТОРЕННЯ У ЗИМОВІЙ ПОВІСТІ ОЛЕСЯ УЛЬЯНЕНКА
}

\author{
ФЕЛІКС ШТЕЙНБУК \\ Університет Яна Коменського у Братиславі, Братислава — Словаччина \\ feliks.shteinbuk@uniba.sk; ORCID:0000-0002-4852-815X \\ ARCHETYPOWE TŁO I POETYKA POWTÓRZENIA
W ZIMOWEJ OPOWIEŚCI OŁESIA ULIANENKI
}

FELIKS SZTEJNBUK

Uniwersytet Jana Komeńskiego w Bratysławie, Bratysława — Słowacja

\begin{abstract}
STRESZCZENIE. W prezentowanym artykule zaproponowana została oryginalna, w przeciwieństwie do wielu wcześniejszych odczytań Zimowej opowieści Ołesia Ulianenki zazwyczaj opartych na podejściu socjologicznym, psychoanalityczna interpretacja tego dzieła, sięgająca głęboko do poetyki utworu. Przeprowadzona analiza dowodzi, że w niewielkim, ale znakomitym pod względem artystycznym szkicu, który trudno przypisać do określonego gatunku i w którym niełatwo wyznaczyć fabułę i temat, ukraiński pisarz w skondensowanej formie zaprezentował liczne wieloaspektowe i sugestywne obrazy archetypowe, ściśle powiązane z problematyką wspólnotowo-historyczną, moralno-etyczną, fillozoficzną (immanentnie obecną w jego późniejszych pracach). Ponadto, co najważniejsze, autor udowodnił, że śmierć można pokonać dzięki powtarzającym się zwycięstwom.

Słowa kluczowe: Ołeś Ulianenko, socjologia, interpretacja psychoanalityczna, obrazy archetypowe, powtórzenia, śmierć.
\end{abstract}

\section{ARCHETYPE SUBSTRATUM AND POETICS OF REPETITION IN OLES ULIANENKO'S ZYMOVA POVIST}

FELIKS SHTEINBUK

Comenius University in Bratislava, Bratislava — Slovakia 
ABSTRACT. Unlike many previous ones which contained authors' socially conditioned interpretations of Oles Ulianenko's works, the article suggests an original, poetically determined, psychoanalytical reading of Zymova povist. As a result, the conclusion is that in this short but aesthetically powerful work of fiction of unclear genre, plot and theme, the Ukrainian author offers a concentrated, concise presentation of polysemous and expressive archetype images, which are obviously connected with social-historical, moral-ethical, and philosophical subject matter which found its in-depth representation in his later literary work. Above all, however, in this particular work of fiction, Ulianenko depicts how death is defeated by repeated victory.

Keywords: Oles Ulianenko, sociologism, psychoanalytical interpretation, archetype images, repetition, death.

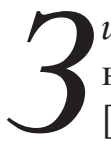

имова повість О. Ульяненка, на думку Н. Зборовської, „стала своєрідним підсумком «революційної» юності прозаїка. Вона започаткувала [...] характерну для О. Ульяненка химерно-похмуру картину світу”, на якій „на тлі «білої безмежі», монотонно застиглого світу-снігопаду, на тлі мертвотно безкрайого і безглуздого міста вештається неприкаяна чорна постать озлобленого чоловіка" [Зборовська 2019]. Переважно у соціологічному контексті розглядає колізії цього твору і Н. Тендітна, а тому, на їі переконання, „навіть постійний рев винищувачів звучить як заупокійна молитва за невинно убієнними жертвами" [Тендітна 2010: 131]. Своєю чергою, більш ніж жорстку позицію зайняла Р. Харчук, яка не тільки ствердила, що „Зимова повість виражає анархічний світогляд автора, втілений в образі колишнього терориста, який зневірився в тій державі, яку виборював на початку 90-х”, а й фактично перейшла на особистість Олеся Ульяненка, звинувативши письменника в тому, що він ,у Зимовій повісті з християнського мораліста перетворюється на войовничого анархіста”, позаяк „його лояльність до держави, точніше, до посткомуністичної еліти, яка дала премію, $є$ не суперечністю, а пристосуванством або, за висловом того ж О. Ульяненка, прагненням «вдало примостити свою задницю»" [Харчук 2008: 95-96]. Не думаю, що наведені пасажі потребують узагалі якихось коментарів хоча б тому, що якби рецепція творів будь-якого автора визначалася його морально-етичною поставою, то від всесвітньої літератури залишилось би, певно, лише кілька творів давньогрецьких авторів, і то тільки тому, що ми нічого не знаємо про особисте життя останніх.

Натомість на цьому тлі, безперечно, більш глибокого змісту щодо проблематики Зимової повісті спробувала сягнути О. Пуніна, яка переконана в тому, що „зазначені критикою змістові форманти роману — екзистенційність, втілена ідея конечності, семантика крокуючої смерті тощо - трансльовано через образ безіменного головного героя-поета, покликаного виконати місію звільнення своєї країни від виродженця-диктатора" [Пуніна 2014: 207]. Крім того, у наведеному періоді поєдналися як вже традиційні соціологічні детермінанти, так і принаймні термінологічні вияви філософії існування. Втім, і в 
цьому разі авторці не до снаги було втриматися на рівні усвідомлення змісту аналізованого твору в екзистенційних категоріях, а тому О. Пуніна доходить висновку, за яким „смерть, що дає надію на відродження, ознаменовує й остання сцена у Зимовій повісті - початку війни: поховання безіменного героя супроводжується активним людським протестом, про позитивне завершення якого свідчить алегорична розмова в структурній частині $P$. $S$. про гній та нові парості пшениці на ньому. Чого, власне, й прагнулося головному герою-поету, який такою настановою близький до місії експресіоністів: зробити спробу змінити світ" [Пуніна 2014: 209].

Відтак зі змісту згаданої статті важко збагнути, який стосунок до історії про анонімного героя-поета мають засади експресіоністської естетики. Але не можна відмовити й О. Пуніній, і Н. Тендітній у тому, що тексти цих авторок все ж таки не позбавлені цікавих спостережень, які, щоправда, майже вщент руйнують заявлені у назвах статей дослідницькі аспірації. Зокрема, в обох розвідках, присвячених темі смерті - тільки з непереконливими намаганнями розглянути цю тему в психоаналітичному ключі Н. Тендітною, a О. Пуніною - у ключі екзистенційному, — йдеться, з одного боку, про те, що головний герой $є$ поетом, а з іншого боку, Н. Тендітна зазначає, що „автор застосовує прийом контрасту для підсилення трагічності розв'язки сюжету роману”, через що „останні хвилини життя героя проходять на фоні пейзажу весняного буяння природи. і він радіє тому, що наостанок ще може «вільно дихати, впиватися миром»" [Тендітна 2010: 133]. А О. Пуніна взагалі вдається до блюзнірського, по суті, твердження, за яким „у випадку з безіменним героєм-поетом йдеться про смерть іншого гатунку, грунт для якої підготовлено зокрема і зустріччю $з$ жінкою, якій вдається витворити в персонажеві сподівання на життя після смерті" [Пуніна 2014: 209].

Тож необхідно зазначити, що обидві авторки, скоріше за все навіть не усвідомлюючи цього, пишуть про стару і всім дуже добре відому історію, яка майже дві тисячі років тому сталася з іще одним, за версією В. Висоцького, поетом, себто Христом, і яка набула характеру всесвітньої містерії, що, попри свій трагічний вимір, все ж таки продовжує щороку утверджувати життєдайне "весняне буяння природи" і неабияк підсилює “сподівання на життя після смерті". Зрозуміло, що за такого контексту некрофільські інтенції, які постійно інкримінуються тією ж, наприклад, Н. Тендітною Олесю Ульяненку, набувають виразно протилежного штибу остільки, оскільки чи не кожна релігія — і християнська аж ніяк не становить винятку з цього правила! — постає у зв'язку зі страхом перед смертю, а отже, живиться, так би мовити, небуттям задля утвердження життя.

Чи присутні у цій містерії садистичні мотиви? Безперечно. Зрештою, так само, як і мазохістські. Проте не думаю, що такий кшталт психоаналізу може вважатися продуктивним. Принаймні стаття Н. Тендітної доводить прямо про- 
тилежне, адже за версією, яку в ній викладено, той, хто добровільно прирік себе на смерть, водночас виступає і як подібний до офіцера зі стеком носієм садистичного начала, який (носій) „нарешті наважується на вбивство”, „спостерігає, як безсило намагаються захистити [Генерала] охоронці, як страх паралізує волю цієї людини”, і який „знає, що сьогодні Генерал має загинути, а тому відтягує момент пострілу, ніби смакуючи свою перемогу" [Тендітна 2010: 132].

А тому не зовсім зрозуміло, на якій підставі літературознавиця робить висновок про те, що „роман О. Ульяненка, як і переважна більшість його творів, закінчується смертю головного героя. Але в жодному з тих творів фінал не набуває такого оптимістичного звучання, як у Зимовій повісті"? Також зовсім не зрозуміло, чому „некрофілічно-садистський простір міста постає для поета тим тлом, на якому його смерть стає насущною осмисленою необхідністю" [Тендітна 2010: 134]. І вже поготів важко втямити, як усе це корелює з позицією О. Пуніної, яка переконана в тому, що „смерть стає невід’ємною складовою його [головного героя-поета] миті-існування, що в Зимовій повісті прочитується на семантичному рівні за рахунок виражально-зображальних ресурсів, що оформлюють наскрізні взаємопов' язані мотиви мертвості й спогаду (пам’ яті) - на початку роману ув'язнений герой напередодні розстрілу вдається до типової речі у передсмертний момент - згадок” [Пуніна 2014: 207].

Якщо підсумувати наведені вище рації, то може скластися враження, що у Зимовій nовісті в надзвичайно похмурому чи, сказати б, навіть у зимово-пригніченому стилі розповідається про відчайдуха, який жертвує своїм життям заради звільнення країни від тирана. Але чомусь нікого не бентежить той факт, що, по-перше, твір називається не Як гартувалася сталь, і не Це солодке слово - свобода! і навіть не Вбити дракона чи якось у подібному дусі, а майже пасторально - Зимова повість. По-друге, у цій “повісті”, яку нібито присвячено громадянському герцю, крім відсутності головного героя, що, будучи поетом, не має, проте, імені, більшість персонажів репрезентована доволі умовно. Виняток становить тільки кохана поета Оксана, яку вбили через нього, а щодо інших, то це - Леф, Жид, Генерал, Кат, “чоловік у чорному”, “жінка з очима лані”, номінація яких у такий спосіб цілком вписується і у принаймні амбівалентне місце жінки у долі поета, і в цілком штучний дискурс Зимової повісті.

Адже у творі йдеться про невідому країну, якою, з оглядкою на зимову сльоту і холоднечу, могла б стати будь-яка центрально- чи північноєвропейська “ойкумена”, либонь, за винятком Ісландії, в якій просто немає ні євреїв, ані генералів, ані катів. Зрештою, навряд чи на приблизно двохсот українців, що проживають натепер в Ісландії, знайдеться хоч одна Оксана, а тому єдиний поіменований персонаж, з одного боку, все ж таки зумовлює звуження 
кількості відповідних держав, а з іншого - i справді засвідчує вагомість ролі цього жіночого образу у загальній концепції аналізованого твору.

Досить складно позбутися враження і стосовно того, що зміст “повісті" буцімто вирвано як з історико-національно-культурного, так і з темпорально-просторового контексту, внаслідок чого твір Олеся Ульяненка втрачає і на жанрі роману загалом, і на антиутопічному різновиді цього жару зокрема. Через це можна говорити хіба що про якийсь шкіц, замальовку, власне, про повість чи не в давньоруському значенні цього терміну, коли зміст, можливо, і реальних давніх подій з рації, сказати б, їхнього охудожнювання втрачає на автентичності, але тим самим через свій фікційний характер неабияк посилює художній вимір остаточного результату, за яким „всі плітки стали пророцтвами, а пророцтва плітками" [Ульяненко 2017: 154]. У цьому сенсі особливо показовою мені видається ситуація з ув'язненням головного героя у глибокому підземному „тунелі недобудованого метро” [Ульяненко 2017: 189], в яке він потрапив через переслідування посіпак Генерала і з якого неймовірно-героїчними зусиллями він намагався у прямому значенні цього слова видряпатися. Отож вагомий сенс цього епізоду полягає в тому, що герой-поет уже вдруге після помилування уникнув майже неминучої смерті і знову визволився зі смертельно небезпечної пастки.

Сказати б інакше, зміст цього художньо-ліричного шкіцу можна визначити як невпинний рух колом або, точніше, як якесь наврочене ходіння манівцями, спрямоване не тільки на спогади, а й разом з тим на повторення. Але проблема полягає в тому, що повторення як певний феномен має глибокий та парадоксальний зміст. Так, С. Кіркегор писав свого часу про те, що „повторення та спогади - це один і той самий рух, але він спрямований у протилежні сторони: те, що згадується, було в минулому, воно повторюється в напрямку минулого, натомість власне повторення - це спогади, спрямовані вперед" [Кіркегор 1964: 33]. Щобільше, і життя людини, за С. Кіркегором, є нічим іншим, як повторенням: воно ніби вдягає його попередній досвід у новий та цілком реальний одяг буття, у той час як спогади $є$ цілковито спрямованими у минуле, а тому виявляють свою непродуктивність.

Ще рішучіше з цього приводу висловлювався і коментатор М. Гайдегтера Д. Левайн, стверджуючи, що „справжні спогади - це не (тут і далі курсив авт. - Д. Л.) «повторення» в тому сенсі, в якому воно намагається репродукувати досвід минулого, рабськи копіюючи історичний прецедент, це скоріше «повторення» іншого типу — особливим чином і при загостреній свідомості свого власного часу воно готує нас до того, аби ми пережили первісний досвід Буття..." [Левайн 1985: 77]. Утім, за умови, що йдеться про “первісний досвід”, про доособистісне, так би мовити, відчуття Буття; за цієї умови неможливо не погодитися з М. Ямпольським, який стверджує, що подібний досвід $€$ пов'язаним „із нашою тілесністю” [Ямпольський 1996: 133]. 
І в Зимовій повісті Олеся Ульяненка, передусім у згаданому епізоді, тілесна репрезентація дається взнаки в чи не найбільш драстичний спосіб, який увиразнюється оповіддю про те, що „щурі нахабніли: залазили на обличчя, нишпорили по кишенях, потім їх стало з'являтися все більше і більше”. I вони „ходили виром. Засвічуючи ліхтарик, він бачив, як сірі, руді спини ворушаться, шарудять, а часто, задрімавши, він майже на нюх чув, як якесь неприємне, колюче тепло йшло від того місця, де вони вовтузилися" [Ульяненко 2017: 191].

Необхідно взяти також до уваги, що повторення $є$ не лише процедурою згортання смислу всередину, як це може видатися на перший погляд у зв'язку 3 тим, що шлях героя-поета все одно закінчується смертю. Повторення $€$ нічим іншим, як постійним відновленням присутності, ніби чимось таким, що відмовляється йти у минуле і що спричинює враження, за яким мовлення буцімто завмирає у постійній репрезентації одного й того ж. Натомість питання полягає тільки в тому, аби зрозуміти, про що ж власне йдеться в цьому разі, адже суспільний (а втім, як мені здається, майже національно не ідентифікований) вимір Зимової повісті слугує винятково контрастним тлом для репрезентації буттєвої проблематики, яка визначається фундаментальними архетипами.

Передусім, звісно, йдеться про архетип тирана, представленого образом Генерала, який за всіма традиційними стереотипами постає джерелом нудного та безглуздого насилля - переважно заради насилля, бо, на думку Жида, „танки - це сонячне алегро всіх диктаторів”, й „іншого порятунку людство не придумало" [Ульяненко 2017: 182]. Детермінує цей архетип також і повторення відповідної, проте карнавально перевернутої, тілесної характеристики, що на іншому рівні підкреслює безперспективність карально-вбивчої суспільної системи і що стосується відомого ще з біблійних часів кумедного гріха, який управляв „Генерал, що займався онанізмом по службових кльозетах” [Ульяненко 2017: 158] і „по безкоштовних партійних клозетах” [Ульяненко 2017: 165].

Дещо складніше, хоч і цілком очікувано, репрезентовано у творі архетип Жида, причому, як здається, для автора перш за все важить са́ме архетипний зміст цього персонажа, бо принаймні з прагматичної точки зору пошуки останнього героєм-поетом вмотивовано, якщо висловлюватися стримано, не надто переконливо. Своєю чергою, як вважає Н. Зборовська, „образ мудрого і упослідженого Жида [...] починаючи із Зимової nовісті, формує визначальний іронічно-надмірний інтелектуальний пафос”, а надто — „са́ме цей герой виступає дзеркалом навколишньої недоцільності людини”, бо „Жид із своєю громадською невизначеністю так само гнаний і непотрібний у «незалежній країні», як герой-патріот, котрий воював за державу” [Зборовська 2019].

До цього варто також додати, що спільними між ними є подібна суспільна маргінальність Жида та поета, але водночас і їхня протиставленість соціуму та, сказати б, надлишковість, які у парадоксальний спосіб якраз і уможлив- 
люють неабияку значущість цих постатей. I, мабуть, са́ме тому зміст розмови між цими двома „громадськи невизначеними” достойниками є доволі цікавим, оскільки вони спілкуються чи не всуціль філософськими максимами і з'ясовують, між іншим: будучи суперечливою істотою, людина „в темряві бачить ворогів, хоча це може бути не те й не інше, — а при світлі дня то щире братання, яке мені нагадує скоріш велику братську могилу" [Ульяненко 2017: 180]; „найстрашніше [...] це те, що ми забуваємо, які ми були вчора” [Ульяненко 2017: 181-182]; „філософія звела на престол не одного тирана”; „Бог відбирає нашу мудрість” і „полишає нам цю землю”, „щоб померти на ній”; „краще померти триклятим жидом, аніж бути справжнім патріотом і загинути в ім'я того, чия назва - ніщо”; „кожному свій час”, а тому якщо „чиясь воля”, то „і дрова загоряться” [Ульяненко 2017: 182]. Отже, і поет, і філософ справді переймаються через подібні причини, тобто не тільки через безглуздість насилля і приреченість на смерть, а й через безтямність життя — як їхнього особистого, так і життя взагалі.

Не менш цікавим - тим більше у запропонованому вище контексті мені видається і архетип Ката тому, що цей образ визначається амбівалентно. Так, з одного боку, архетип Ката уособлює смерть, і тим самим підсилює смертоносну сильветку Генерала, будучи виконавцем людиновбивчої волі останнього і в цьому сенсі набуваючи сусnільно-тілесного виміру. 3 іншого боку, через те, що Кат виявляється батьком поета, ця образна диспозиція набуває психоаналітичного, тобто тілесно-суспільного штибу, внаслідок чого у наратив твору вводяться мотиви і безпосередньо, і опосередковано репрезентованого Едіпового комплексу. Якби герой-поет убив звичайного ката, що сприяв утвердженню тиранічної, насильницької та несправедливої влади, то тоді відповідний дискурс і справді надавався б на тлумачення та інтерпретацію у соціологічних категоріях. Але оскільки поет убиває батька, який, як з'ясовується, ще й особисто повісив Оксану, то ця колізія невідворотно набуває принаймні антропологічного значення, яке додатково увиразнюється філософським, у дусі Екклезіаста, монологом Ката, що закликає сина зазирнути йому в очі, бо, мовляв, „снігом там мете, далеким свіжим снігом”. Адже він „пройшов увесь світ і нічого нового не побачив, нічого нового не відкрив, бо немає нічого нового”. Щобільше, „підбирав недокурки, ховався по нужниках, обнишпорив усі смітники людських думок і спочивав на їхніх відкритих свободах, як на недогризках, - доки не повернувся обличчям до Бога i" не вдався до низки блюзнірських і водночас риторичних запитань, на які нікому не до снаги отримати жодної відповіді, але які все ж таки дозволили Кату дійти несподіваного, хоч і святотатственного висновку: „Може, Господи, то Ти тільки тінь, а я вічність у Твоїй подобі?” [Ульяненко 2017: 185].

Неможливо обминути в цьому контексті й архетип жінки, зокрема, представлений у Зимовій повісті двома персонажами, - замордованою Катом 
Оксаною і анонімною „жінкою з очима лані” [Ульяненко 2017: 196, 197, 198]. Через ці образи більш ніж виразно актуалізується характерна для них амбівалентна символіка, що промовляє не тільки до життєдайного, а й до смертоносного начала. а відтак архетип „чоловіка у чорному” [Ульяненко 2017: $174,176,177]$ навіть не потребує додаткових коментарів, крім того, що цей образ, починаючи з готичних романів і закінчуючи сучасними романами жахів, притаманний значною мірою так званій масовій літературі.

Таким чином, можна дійти висновку, за яким у невеличкій, але естетично потужній художній замальовці з невизначеним жанром, сюжетом і тематикою Олесь Ульяненко у концентрованому вигляді репрезентував не лише численні багатозначні й промовисті архетипні образи, пов'язані, безумовно, і з суспільно-історичною, і з морально-етичною, і з філософською проблематикою, що знайшла поглиблене відображення у його подальшій творчості. Найголовніший сенс, як мені здається, полягає в тому, що Зимова повість - це “повість” про смерть, яка долається повторюваним подоланням смерті. Інакше кажучи, митцеві йдеться про художньо-діалектичне заперечення смерті, небезпека повторювання якої імпліцитно справді містить у собі перспективу iï елімінації. Бо кожного разу, коли герой-поет перебуває за крок до смерті, а проте йому вдається утриматися від цього кроку, він тим самим не просто оминає фатальну небезпеку, - він у такий спосіб утверджує життя. I наявність у проаналізованому дискурсі твору Олеся Ульяненка амбівалентно наснажених образів-архетипів додатково доводить слушність запропонованої інтерпретації, на користь вірогідності якої свідчить також дещо дивний фінал у жанрі постскриптуму, що у ньому невідомий чоловік, ще раз ствердивши песимістичний сценарій для розвитку держави, попри це, вдається до алюзії відомого біблійного тексту про „нову парость [...] пшениці”, яка має вирости „на гною” [Ульяненко 2017: 207].

\section{Список використаної літератури}

Зборовська Н., Феміністичні роздуми: На карнавалі мертвих почілунків, [в:] Електронний pecypc: http://1576.ua/books/4774 (24.09.2019).

Пуніна О.В., Художнє осмислення універсалії смерті в „Зимовій повісті” Олеся Ульянен$\kappa a$, [в:] „Вісник Донецького національного університету”, 2014, № 1-2, с. 206-210.

Тендітна Н., Некрофілічно-садистський простір роману О. Ульяненка „Зимовій повісті”, [в:] „Вісник ЛНУ ім. Т. Шевченка”, 2010, № 5, с. 130-135.

Харчук Р.Б., Сучасна українська проза: Постмодерний період, Київ: Академія, 2008.

Ямпольский М., Демон и Лабиринт, Москва: Новое литературное обозрение, 1996.

Kierkegaard S., Repetition: An Essay in Experimental Psychology, New York — Evanston London: Harper \& Row, 1964. 
Levin D., The Body's Recollection of Beingu: Phenomenological Psychology and the Deconstruction of Nihilismu, London: Routlege \& Kegan Paul, 1985.

\section{Список використаних джерел}

Ульяненко О., Там, де Південь, Київ: Люта справа, 2017.

\section{Spysok vykorystanoi literatury [References]}

Zborovska N., Feministychni rozdumy: Na karnavali mertvykh potsilunkiv [Feminist Reflections: at the Carnival of Dead Kisses], [v:] Elektronnyi resurs: http://1576.ua/books/4774 (24.09.2019).

Punina O.V., Khudozhnie osmyslennia universalii smerti v „Zymovii povisti” Olesia Ulianenka [Artistic Realisation of Death's Timelessness in „,Winter Novel” by Oles Ulianenko], [v:] „Visnyk Donetskoho natsionalnoho universitetu”, 2014, № 1-2, s. 206-210.

Tenditna N., Nekrofilichno-sadystskyi prostir romanu O. Ulianenka „Zymovii povisti” [The Space Full of Necrophilia and Sadism in Ulianenko 's ,Winter Novel”], [v:] ,Visnyk LNU im. T. Shevchenka”, 2010, № 5, s. 130-135.

Kharchuk R.B., Suchasna ukrainska proza: Postmodernyi period [Postmodernism in Contemporary Ukrainian Prose], Kyiv: Akdemiia, 2008.

Yampolskii M., Demon i Labirint [A Demon and a Labyrinth], Moskva: Novoie literaturnoie obozreniie, 1996.

Kierkegaard S., Repetition: An Essay in Experimental Psychology, New York — Evanston London: Harper \& Row, 1964.

Levin D., The Body's Recollection of Beingu: Phenomenological Psychology and the Deconstruction of Nihilismu, London: Routlege \& Kegan Paul, 1985.

\section{Spysok vykorystanykh dzherel [References]}

Ulianenko O., Tam, de Pivden [Where South Is], Kyiv: Liuta sprava, 2017. 